\title{
Solid-phase extraction of plutonium in various oxidation states from simulated groundwater using $N$-benzoylphenylhydroxylamine
}

\author{
S. A. Perevalov • G. I. Malofeeva • E. V. Kuzovkina • \\ B. Ya. Spivakov
}

Received: 13 July 2011 / Published online: 4 October 2011

(C) The Author(s) 2011. This article is published with open access at Springerlink.com

\begin{abstract}
Solid-phase extraction of plutonium in different individual and mixed oxidation states from simulated groundwater ( $\mathrm{pH} 8.5$ ) was studied. The extraction of plutonium species was carried out in a dynamic mode using DIAPAK C16 cartridges modified by $N$-benzoylphenylhydroxylamine (BPHA). It was shown that the extent of recovery depends on the oxidation state of plutonium. The extraction of $\mathrm{Pu}(\mathrm{IV})$ was at the level of 98-99\% regardless of the volume and flow-rate of the sample solution. $\mathrm{Pu}(\mathrm{V})$ was extracted by $90-95 \%$ and $75-80 \%$ from 10 - and 100-mL aliquots of the samples, respectively, whereas the extraction of $\mathrm{Pu}(\mathrm{VI})$ did not exceed $45-50 \%$. An equimolar mixture of $\mathrm{Pu}(\mathrm{IV}), \mathrm{Pu}(\mathrm{V})$, and $\mathrm{Pu}(\mathrm{VI})$ was extracted by $74 \%$. The distribution coefficients $\left(K_{\mathrm{d}}\right)$ and kinetic exchange capacities $(S)$ of plutonium in various oxidation states were measured. It was found that during the sorption process, $\mathrm{Pu}(\mathrm{V})$ was reduced to $\mathrm{Pu}(\mathrm{IV})$ by $80-90 \%$ after an hour-long contact with the solid phase. $\mathrm{Pu}(\mathrm{VI})$ is reduced to $\mathrm{Pu}(\mathrm{V})$ by $34 \%$ and to $\mathrm{Pu}(\mathrm{IV})$ by $55 \%$. In the case of mixedvalent solution of plutonium, only $\mathrm{Pu}(\mathrm{V})$ and $\mathrm{Pu}(\mathrm{IV})$ were found in the effluents.
\end{abstract}

Keywords Solid-phase extraction - Plutonium . $N$-benzoylphenylhydroxylamine · Groundwater

\footnotetext{
S. A. Perevalov $(\bowtie) \cdot$ G. I. Malofeeva ·

E. V. Kuzovkina · B. Ya. Spivakov

V. I. Vernadsky Institute of Geochemistry and Analytical

Chemistry, Russian Academy of Sciences (GEOKHI RAS),

Kosygina St. 19, 119991 Moscow, Russian Federation

e-mail: perevalov@geokhi.ru

G. I. Malofeeva

e-mail: malofeeva@geokhi.ru

B. Ya. Spivakov

e-mail: spivakov@geokhi.ru
}

\section{Introduction}

Among the radionuclides present in radioactive wastes, there are a certain number of fission products and minor actinides. Actinides and particularly long-lived isotopes of plutonium are mainly responsible for the environmental hazard. Extensive studies during the last decades have shown that under the natural conditions $\mathrm{Pu}$ can be simultaneously stabilized in four oxidation states: $+3,+4,+5$, and $+6 . \mathrm{Pu}(\mathrm{III})$ and $\mathrm{Pu}(\mathrm{IV})$ are more stable in acidic media, while the higher oxidation states are predominant in the solutions with $\mathrm{pH} \geq 7$. At certain concentrations at $\mathrm{pH} 2-3$ $\mathrm{Pu}(\mathrm{IV})$ has a strong tendency to hydrolysis, giving rise to the formation of polymeric species [1].

For risk assessment, monitoring of plutonium concentration in contaminated zones is required. Several methods are frequently used for the determination of plutonium speciation in different environmental samples [2, 3]. Apart from liquid-liquid extraction based on a different complexation of various oxidation states of plutonium with various extraction agents, solid-phase extraction (SPE) methods are also fairly effective for the purpose of plutonium speciation [4]. Of a range of chelating reagents available for the SPE of metal ions, benzoylphenylhydroxylamine (BPHA) appears to be one of the most efficient reagents. Being a typical chelating reagent with a rigid bidentate O,O-chelating group [5-7], BPHA has also found application for plutonium recovery from acidic solutions by liquid-liquid extraction [8].

Likewise, SPE on C16 cartridges modified with BPHA has already been demonstrated to be effective for $\mathrm{Np}(\mathrm{V})$, $\mathrm{Pu}(\mathrm{IV})$, and Am(III) extraction from simulated groundwater solutions and surface water taken from the region of Product Association "Mayak" [9]. This provided us with an impetus that using a similar SPE hardware, plutonium in 
its various oxidation states could also be subject to selective extraction.

\section{Experimental}

\section{Chemicals and reagents}

Stock solutions of $239 \mathrm{Pu}\left({ }^{241} \mathrm{Am}\right.$ content did not exceed $0.1 \% \mathrm{w} / \mathrm{v}$ ) in oxidation states $+4,+5$, and +6 were prepared using the following methods. $\mathrm{Pu}(\mathrm{IV})$ was obtained by electrochemical oxidation of $\mathrm{Pu}$ (III) in a hydrochloric acid solution prepared by dissolving a known amount of metallic plutonium in $6 \mathrm{M} \mathrm{HCl}$, using a platinum anode at a potential of $1.2 \mathrm{~V} . \mathrm{Pu}(\mathrm{VI})$ was prepared by the oxidation of tetravalent plutonium in a hot perchloric acid solution followed by evaporation till a wet-salt state. Subsequently, the dry residue was dissolved in water and the resultant solution was evaporated several times. $\mathrm{Pu}(\mathrm{V})$ solution was obtained by reducing $\mathrm{Pu}(\mathrm{VI})$ in a solution with $\mathrm{pH} 2$ using hydrogen peroxide. Plutonium concentrations in the stock solutions were $(5-10) \times 10^{-3} \mathrm{M}$. Working solutions were prepared by dilution of stock solutions with the required volume of SGW having the following composition (in $\mathrm{g} / 10 \mathrm{~L}$ ): $\mathrm{Na}_{2} \mathrm{CO}_{3}-0.276, \mathrm{CaCl}_{2}-0.079, \mathrm{AlCl}_{3}-0.00047, \mathrm{Na}_{2} \mathrm{SiO}_{3}$. $9 \mathrm{H}_{2} \mathrm{O}-0.279, \mathrm{NaHCO}_{3}-2.483, \mathrm{Na}_{2} \mathrm{SO}_{4}-0.185, \mathrm{NaCl}-$ $0.176, \mathrm{KCl}-0.045 ; \mathrm{pH}$ 8,5. Aliquots of the individual solutions of $\mathrm{Pu}(\mathrm{IV}), \mathrm{Pu}(\mathrm{V})$, and $\mathrm{Pu}(\mathrm{VI})$ were introduced into $100 \mathrm{~mL} \mathrm{SGW}$ and a mixed solution $\mathrm{pH}$ was adjusted and $\mathrm{Eh}$ was measured. All chemicals used were of analytical grade.

\section{Instrumentation}

Plutonium species in the solutions obtained were monitored using spectrophotometers "Unicam UV-300" and "Cary 100".

Hydrolyzed and polymerized forms of plutonium were identified by ultrafiltration at 14,000 rpm. using a "SM-50" centrifuge. Separation of particles with molecular masses of $30 \mathrm{kDa}$ and larger was performed by centrifugation during $30 \mathrm{~min}$ by use of filters with $3 \mathrm{~nm}$ pore sizes. Concentration of ionic and polymeric forms of plutonium was estimated from a difference in plutonium concentrations before and after ultrafiltration. DIAPAK C16 cartridges purchased from BioChimMak, MSU (Moscow State University, Russia) were applied to the investigation of plutonium speciation. It is a silica material chemically modified with hexadecyl groups $\left(\mathrm{SiO}_{2}-\mathrm{OSi}-\left(\mathrm{CH}_{3}\right)_{2} \mathrm{C}_{16} \mathrm{H}_{33}\right)$ having an average pore size of $130 \mathrm{~nm}$, the specific surface area of $300 \pm 30 \mathrm{~m}^{2}$ per $\mathrm{g}$ and size distribution in the range of $50-160 \mu \mathrm{m}$.

Each cartridge was conditioned by flushing with $5 \mathrm{~mL}$ ethanol and then modified by passing through $10 \mathrm{~mL}$ of $0.2 \mathrm{M}$ BPHA in ethanol. The sorption of plutonium was studied under dynamic conditions by passing the $\mathrm{Pu}$-containing solutions through the cartridge at a flow-rate of $1 \mathrm{~mL} / \mathrm{min}$. $10 \mathrm{~mL}$ aliquots of the filtrate were collected after certain time intervals to monitor the variation in plutonium concentration. After the sorption equilibrium was achieved, plutonium was desorbed by $0.1 \mathrm{M} \mathrm{HNO}_{3}$ and the mixed acids solution of $0.35 \mathrm{M} \mathrm{HNO}_{3}+0.01 \mathrm{M}$ HF was studied.

Liquid-liquid extraction with a $0.2 \mathrm{M}$ 2-thenoyltrifluoroacetone (TTA) solution in toluene was additionally used to estimate the $\mathrm{Pu}$ speciation in the effluent after desorption. After the separation of aqueous and organic phases, the plutonium concentrations in each phase were determined, as described below.

Alpha-spectrometry was employed for the determination of plutonium concentration. An aliquot of the test solution was evaporated to dryness on polished stainless-steel targets $(d=30 \mathrm{~mm})$, following by the target calcination at about $500{ }^{\circ} \mathrm{C}$. Alpha-spectra were acquired using an "Alpha Analyst" spectrometer (Canberra, USA). For pH measurements a pH-meter "Mettler Toledo" MP230 equipped with a combined glass electrode (Hanna Instrument HI 1131B) was used. The electrode was regularly calibrated with respect to $\mathrm{pH}$-buffer standards ( $\mathrm{pH} \mathrm{1-13;}$ Merck, Darmstadt, Germany). In SPE experiments, the required $\mathrm{pH}$ was adjusted with solutions $0.1 \mathrm{M} \mathrm{NaOH}$ or $0.1 \mathrm{M} \mathrm{HClO}_{4}$. Monitoring of redox potentials (Eh) was performed by a platinum grid using the $\mathrm{Ag} / \mathrm{AgCl}$ electrode as a reference one.

The dynamic capacity $(S, \mathrm{M} / \mathrm{g})$ and the distribution coefficients $\left(K_{\mathrm{d}}, \mathrm{mL} / \mathrm{g}\right)$ were calculated from the following equations:

$S=\left(C_{0}-C_{\mathrm{e}}\right) \times V / m$

$K_{\mathrm{d}}=S \times 1000 / C_{\mathrm{e}}$

where $\mathrm{C}_{0}$ is the initial concentration of plutonium in the solution (M), $C_{\mathrm{e}}$ is the plutonium concentration in the ultra filtrate $(\mathrm{M}), V(\mathrm{~mL})$, and $m$ is the mass of the sorbent $(\mathrm{g})$.

\section{Results and discussion}

Characteristics of initial SGW solutions of plutonium in various oxidation states used in this study are presented in Table 1. As can be seen, the higher the redox potential of the solution, the higher oxidation state of plutonium is stabilized. This observation is in agreement with the data of Choppin et al. [10]. After ultrafiltration, the plutonium concentration in the filtrate corresponds to the concentration of its ionic forms and the quantity of $\mathrm{Pu}$ retained by the filter is in accordance with the concentration of its polymeric forms. Under the present conditions, $\mathrm{Pu}$ (IV) hydrolyses results in the formation of polymeric species that was 
Table 1 Speciation of $\mathrm{Pu}$ in the initial SGW solutions

\begin{tabular}{llllll}
\hline $\begin{array}{l}\mathrm{Pu} \\
\text { oxidation } \\
\text { state }\end{array}$ & {$[\mathrm{Pu}]_{\mathrm{tot}}(\mathrm{M})$} & $\mathrm{pH}$ & $\begin{array}{l}\mathrm{Eh} \\
(\mathrm{mV})\end{array}$ & {$[\mathrm{Pu}]_{\text {filtrate }}(\mathrm{M})$} & $\begin{array}{l}\text { Ratio of } \\
\text { ionic } \\
\text { form }(\%)\end{array}$ \\
\hline $\mathrm{Pu}(\mathrm{IV})$ & $6.05 \times 10^{-6}$ & 8.76 & 356 & $4.84 \times 10^{-7}$ & 8.0 \\
$\mathrm{Pu}(\mathrm{V})$ & $4.23 \times 10^{-6}$ & 8.61 & 406 & $3.76 \times 10^{-6}$ & 88.9 \\
$\mathrm{Pu}(\mathrm{VI})$ & $6.22 \times 10^{-6}$ & 8.27 & 582 & $5.97 \times 10^{-6}$ & 99.0 \\
$\mathrm{Pu}$ mixture & $7.27 \times 10^{-6}$ & 8.45 & 532 & $4.42 \times 10^{-6}$ & 60.8 \\
\hline
\end{tabular}

confirmed by the results of ultrafiltration experiments. It was shown that nearly $92 \%$ of tetravalent plutonium in the solutions occurs in polymeric forms.

$89 \% \mathrm{Pu}(\mathrm{V})$ presents in ionic forms and the rest $11 \%$ as polymeric forms. This can be due to the disproportion of $\mathrm{Pu}(\mathrm{V})$ according to reaction 3 :

$2 \mathrm{PuO}_{2}^{+}+4 \mathrm{H}^{+} \leftrightarrow \mathrm{Pu}^{4+}+\mathrm{PuO}_{2}^{2+}+2 \mathrm{H}_{2} \mathrm{O}$

As a result, some amount of $\mathrm{Pu}(\mathrm{IV})$ is produced, which then undergoes polymerization, whereas $99 \%$ of $\mathrm{Pu}(\mathrm{VI})$ remains in the ionic forms.

In order to estimate the reciprocal influence of different oxidation states of $\mathrm{Pu}$ on its sorption from the solution containing all three forms, $\mathrm{Pu}(\mathrm{IV}), \mathrm{Pu}(\mathrm{V})$, and $\mathrm{Pu}(\mathrm{VI})$, at equal concentration ratios was studied.

Results of SPE experiments are shown in Fig. 1 in the form of dependences of $\mathrm{Pu}$ ratios (in \%) remained in the effluent after passing of $\mathrm{Pu}(\mathrm{IV}), \mathrm{Pu}(\mathrm{V})$, and $\mathrm{Pu}(\mathrm{VI})$ and the mixed-valent $\mathrm{Pu}$ solution through the SPE cartridge modified by BPHA.

As one can see, the SPE behavior of plutonium in various oxidation states differs rather considerably. The polymerized forms of $\mathrm{Pu}(\mathrm{IV})$ are sorbed rather effectively

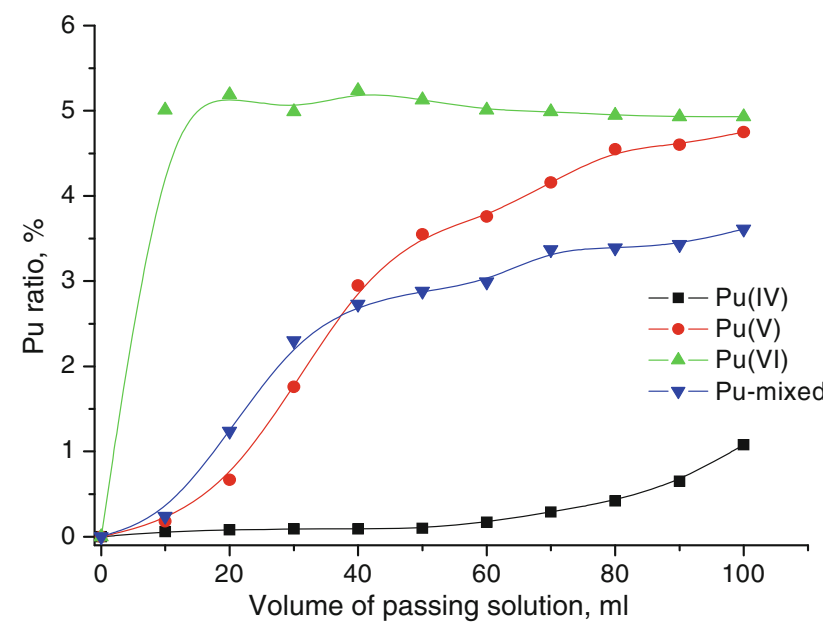

Fig. 1 The ratios of $\mathrm{Pu}(\mathrm{IV}), \mathrm{Pu}(\mathrm{V}), \mathrm{Pu}(\mathrm{VI})$ and mixed-valent $\mathrm{Pu}$ obtained after passing through the cartridge modified by BPHA during passing the first $50 \mathrm{~mL}$ of the solution, that is due to a high sorption affinity of polymeric plutonium macromolecules [11-13]. Further passing the solution results in an increase of plutonium concentration in the effluent that may be attributed to the reduction of $\mathrm{Pu}(\mathrm{IV})$ to $\mathrm{Pu}(\mathrm{III})$ under the action of BPHA, as reported in [8], or to plutonium disproportionation [14]:

$2 \mathrm{Pu}^{4+}+2 \mathrm{H}_{2} \mathrm{O}=\mathrm{Pu}^{3+}+\mathrm{PuO}_{2}^{+}+4 \mathrm{H}^{+}$

$\mathrm{PuO}_{2}^{+}+\mathrm{Pu}^{4+}=\mathrm{Pu}^{3+}+\mathrm{PuO}_{2}^{2+}$

$3 \mathrm{Pu}^{4+}+2 \mathrm{H}_{2} \mathrm{O}=2 \mathrm{Pu}^{3+}+\mathrm{PuO}_{2}^{2+}+4 \mathrm{H}^{+}$

Because the disproportionation may take place according to reactions 4-6, $\mathrm{Pu}(\mathrm{III}), \mathrm{Pu}(\mathrm{V})$, and $\mathrm{Pu}(\mathrm{VI})$ can be found in the equilibrium solution. In these oxidation states $\mathrm{Pu}$ is less inclined to sorption, while the extent of $\mathrm{Pu}(\mathrm{IV})$ extraction under these conditions reaches $97 \%$.

The behavior of $\mathrm{Pu}(\mathrm{V})$ is completely different. Its concentration, after the elution of the first $5-10 \mathrm{~mL}$, changes only slightly since the polymeric $\mathrm{Pu}(\mathrm{IV})$ comprises about $11 \%$ of total $\mathrm{Pu}$. Upon passing the following $30 \mathrm{~mL}$, a sharp increase in the plutonium concentration in the eluate is observed. A further concentration increase is also controlled either by reduction or disproportionation [see reaction 3]. It was also found that the $\mathrm{Pu}(\mathrm{V})$ sorption depends on the volume of the solution passed through the cartridge or, in other words, on the time of contact of the solution with the SPE material. The Pu sorption changes from $85-90 \%$ when $10 \mathrm{~mL}$ of the solution has been passed to $75-78 \%$ for $100 \mathrm{~mL}$ (i.e. 10 and $100 \mathrm{~min}$, respectively). This observation is in agreement with the $\mathrm{Pu}(\mathrm{V})$ disproportionation, being the second-order reaction for plutonium cations.

The sorption rate of $\mathrm{Pu}(\mathrm{VI})$ seems to be constant upon passing the whole volume of the solution, reaching a plateau after loading $10 \mathrm{~mL}$. Pu(VI) is sorbed by about $50 \%$ in case of a $100-\mathrm{mL}$ sample under these conditions.

The mixed-valent plutonium species sorbed by $74 \%$.

The exchange capacities and distribution coefficients for $\mathrm{Pu}(\mathrm{IV}), \mathrm{Pu}(\mathrm{V})$, and $\mathrm{Pu}(\mathrm{VI})$, as well as of mixed-valent plutonium forms are listed in Table 2. It can be seen that the exchange capacity of plutonium ions in all the oxidation states do not decrease much with increasing the solution volume passed through the cartridge.

The distribution coefficients of plutonium significantly depending on the oxidation states and the volume of solution passed through the cartridge. The $K_{\mathrm{d}}$, for $\mathrm{Pu}(\mathrm{IV})$ sorbed from the first $20-25 \mathrm{~mL}$ is relatively high, $2,700-2,000 \mathrm{~mL} / \mathrm{g}$. For $\mathrm{Pu}(\mathrm{IV})$ a rather complicated dependence of $K_{\mathrm{d}}$ on the volume of solution was obtained. This might be due to either the reduction of $\mathrm{Pu}(\mathrm{IV})$ to $\mathrm{Pu}(\mathrm{III})$, or to $\mathrm{Pu}(\mathrm{IV})$ disproportionation and formation of 
Table 2 Exchange capacities and distribution coefficients of $\mathrm{Pu}(\mathrm{IV}), \mathrm{Pu}(\mathrm{V}), \mathrm{Pu}(\mathrm{VI})$, and mixed-valent plutonium species as a function of the volume of solution passed through the sorbent

\begin{tabular}{|c|c|c|c|c|c|c|c|c|}
\hline \multirow[t]{2}{*}{$V(\mathrm{~mL})$} & \multicolumn{2}{|l|}{$\mathrm{Pu}(\mathrm{IV})$} & \multicolumn{2}{|l|}{$\mathrm{Pu}(\mathrm{V})$} & \multicolumn{2}{|l|}{$\mathrm{Pu}(\mathrm{VI})$} & \multicolumn{2}{|l|}{$\mathrm{Pu}$ mixed } \\
\hline & $S(\mathrm{M} / \mathrm{g})$ & $K_{\mathrm{d}}(\mathrm{mL} / \mathrm{g})$ & $S(\mathrm{M} / \mathrm{g})$ & $K_{\mathrm{d}}(\mathrm{mL} / \mathrm{g})$ & $S(\mathrm{M} / \mathrm{g})$ & $K_{\mathrm{d}}(\mathrm{mL} / \mathrm{g})$ & $S(\mathrm{M} / \mathrm{g})$ & $K_{\mathrm{d}}(\mathrm{mL} / \mathrm{g})$ \\
\hline 10 & $1.00 \times 10^{-4}$ & 2,749 & $6.92 \times 10^{-5}$ & 901 & $5.16 \times 10^{-5}$ & 17 & $1.18 \times 10^{-4}$ & 686 \\
\hline 20 & $1.00 \times 10^{-4}$ & 2,084 & $6.57 \times 10^{-5}$ & 229 & $4.97 \times 10^{-5}$ & 15 & $1.06 \times 10^{-4}$ & 117 \\
\hline 30 & $1.00 \times 10^{-4}$ & 1,913 & $5.80 \times 10^{-5}$ & 77 & $5.19 \times 10^{-5}$ & 17 & $9.33 \times 10^{-5}$ & 56 \\
\hline 40 & $9.99 \times 10^{-5}$ & 1,749 & $4.95 \times 10^{-5}$ & 39 & $4.92 \times 10^{-5}$ & 15 & $8.81 \times 10^{-5}$ & 44 \\
\hline 50 & $9.98 \times 10^{-5}$ & 1,595 & $4.53 \times 10^{-5}$ & 30 & $5.03 \times 10^{-5}$ & 16 & $8.62 \times 10^{-5}$ & 41 \\
\hline 60 & $9.92 \times 10^{-5}$ & 989 & $4.38 \times 10^{-5}$ & 27 & $5.16 \times 10^{-5}$ & 17 & $8.49 \times 10^{-5}$ & 39 \\
\hline 70 & $9.79 \times 10^{-5}$ & 552 & $4.10 \times 10^{-5}$ & 23 & $5.18 \times 10^{-5}$ & 17 & $8.03 \times 10^{-5}$ & 33 \\
\hline 80 & $9.65 \times 10^{-5}$ & 375 & $3.82 \times 10^{-5}$ & 20 & $5.23 \times 10^{-5}$ & 17 & $8.01 \times 10^{-5}$ & 32 \\
\hline 90 & $9.42 \times 10^{-5}$ & 238 & $3.78 \times 10^{-5}$ & 19 & $5.24 \times 10^{-5}$ & 17 & $7.96 \times 10^{-5}$ & 32 \\
\hline 100 & $8.99 \times 10^{-5}$ & 138 & $3.68 \times 10^{-5}$ & 18 & $5.25 \times 10^{-5}$ & 17 & $7.74 \times 10^{-5}$ & 29 \\
\hline
\end{tabular}

$\mathrm{Pu}(\mathrm{III}), \mathrm{Pu}(\mathrm{V})$, and $\mathrm{Pu}(\mathrm{VI})$ that causes a lower plutonium sorption.

The distribution coefficient for $\mathrm{Pu}(\mathrm{V})$ decreases drastically when passing the first $30 \mathrm{~mL}$ of the solution, and then levels-off after passing $40 \mathrm{~mL}$. The initial decreasing may be explained by disproportionation or reduction of $\mathrm{Pu}(\mathrm{V})$ to $\mathrm{Pu}(\mathrm{IV})$. The same trend was observed for the mixed-valent plutonium solution. In contrast to other oxidation states, the distribution coefficient for $\mathrm{Pu}(\mathrm{VI})$ remains virtually unchanged within the whole sorption procedure (up to $100 \mathrm{~mL}$ of the passed solution).

The oxidation states of plutonium existing in the sorption process were identified using spectrophotometric studies. The molar absorptivities $(\varepsilon)$ were preliminarily calculated from the absorption spectra of Pu solutions (in $\mathrm{SGW}$ ) in a specified oxidation state at the known plutonium concentration. The values of $(\varepsilon)$, as well as the wavelength of maximum plutonium absorption $(\lambda)$ and absorbance $(D)$ are given in Table 3.

$100 \mathrm{~mL}$ portions of the prepared solutions were passed through the modified cartridges and then plutonium was eluted using a mixed solution of acids $0.35 \mathrm{M}$ $\mathrm{HNO}_{3}+0.01 \mathrm{M} \mathrm{HF}$. If complete plutonium desorption was not reached, the mixed solution of acids $1.0 \mathrm{M}$ $\mathrm{HNO}_{3}+0.01 \mathrm{M} \mathrm{HF}$ was used. It was supposed that during the sorption the plutonium oxidation state does not change. The volume of acids taken for desorption was equal to $10 \mathrm{~mL}$ hereby tenfold plutonium concentration was reached. After the desorption of $\mathrm{Pu}$ from the column was completed, the absorption spectra of the effluents were recorded. The concentration of each oxidized form of plutonium was determined using corresponding absorptivities found earlier.

Figure 2 represents the plutonium oxidation states distribution after the sorption onto BPHA. During the desorption of $\mathrm{Pu}(\mathrm{IV}), 86.2 \%$ of plutonium came out of the
Table 3 Extinction coefficients of $\mathrm{Pu}(\mathrm{IV}), \mathrm{Pu}(\mathrm{V})$ and $\mathrm{Pu}(\mathrm{VI})$ in $\mathrm{SGW}$

\begin{tabular}{lllll}
\hline $\begin{array}{l}\text { Oxidation state } \\
\text { of } \mathrm{Pu}\end{array}$ & {$[\mathrm{Pu}](\mathrm{M})$} & $\begin{array}{l}\lambda \\
(\mathrm{nm})\end{array}$ & $D$ & $\begin{array}{l}\varepsilon \\
\left(\mathrm{M}^{-1} \mathrm{~cm}^{-1}\right)\end{array}$ \\
\hline $\mathrm{Pu}(\mathrm{IV})$ & $9.72 \times 10^{-5}$ & 477 & $2.7 \times 10^{-3}$ & 27.8 \\
$\mathrm{Pu}(\mathrm{V})$ & $9.46 \times 10^{-5}$ & 569 & $1.2 \times 10^{-3}$ & 12.68 \\
$\mathrm{Pu}(\mathrm{VI})$ & $1.04 \times 10^{-4}$ & 831 & $1.4 \times 10^{-2}$ & 134.00 \\
\hline
\end{tabular}

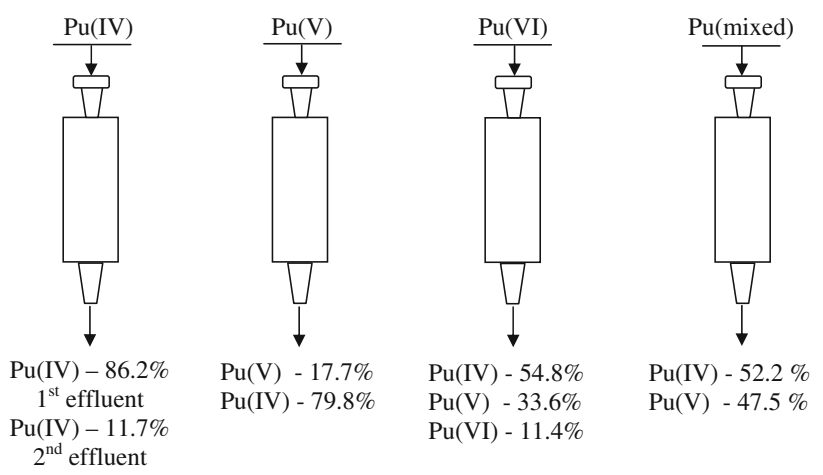

Fig. 2 The plutonium speciation during the sorption onto BPHA ( $100 \%$ corresponds to the total content of $\mathrm{Pu}$ in the respective eluent)

cartridge within passing the first $5 \mathrm{~mL}$ of $0.35 \mathrm{M}$ $\mathrm{HNO}_{3}+0.01 \mathrm{M} \mathrm{HF}$ eluent. An additional 5-mL portion almost completes the recovery of the residual $\mathrm{Pu}(\mathrm{IV})$. $\mathrm{Pu}(\mathrm{V})$ was fully eluted by $10 \mathrm{~mL}$ of $0.35 \mathrm{M} \mathrm{HNO}_{3}+$ $0.01 \mathrm{M}$ HF solution. The absorption spectra have shown up to $80 \%$ of $\mathrm{Pu}$ to be present as $\mathrm{Pu}(\mathrm{IV})$ (the absorption band at $477 \mathrm{~nm}$ ), and the rest exists as $\mathrm{Pu}(\mathrm{V})$ (the absorption band at $569 \mathrm{~nm}$ ). These data are consistent with the suggestion that $\mathrm{Pu}(\mathrm{V})$ is reduced by BPHA during the sorption. $\mathrm{Pu}(\mathrm{VI})$ was also shown to be partially reduced in the cartridge: the effluent contained simultaneously $\mathrm{Pu}(\mathrm{IV})$, 
Table 4 Plutonium extraction by $0.2 \mathrm{M}$ TTA solution in toluene from the SPE eluate. $\left(V=10 \mathrm{~mL}, m_{\text {sorbent }}=100 \mathrm{mg},[\mathrm{Pu}(\mathrm{V})]=\right.$ $\left.1.9 \times 10^{-10} \mathrm{M}\right)$

\begin{tabular}{lllll}
\hline Contact time of sorbent with solution, min & 5 & 10 & 30 & 60 \\
Content of $\mathrm{Pu}(\mathrm{V})$ in the eluate, \% & 97 & 88 & 44 & 10 \\
\hline
\end{tabular}

$\mathrm{Pu}(\mathrm{V})$, and $\mathrm{Pu}(\mathrm{VI})$. This explains the low efficiency of sorption of the hexavalent plutonium from SGW solutions. Mainly tetravalent plutonium is extracted during the sorption process. The eluate obtained by the desorption of mixed-valent plutonium consists of only $\mathrm{Pu}(\mathrm{IV})$ and $\mathrm{Pu}(\mathrm{V})$. Probably, $\mathrm{Pu}(\mathrm{VI})$ is reduced to $\mathrm{Pu}(\mathrm{V})$ or takes part in the following reaction:

$\mathrm{PuO}_{2}{ }^{2+}+\mathrm{Pu}^{4+}=2 \mathrm{PuO}_{2}{ }^{+}$

As a result, a higher amount of $\mathrm{Pu}(\mathrm{V})$ is obtained compared to the initial solution composition.

Liquid-liquid extraction with TTA was additionally used to estimate the $\mathrm{Pu}$ speciation in the eluate after desorption. By varying the time of contact of the test solution with the sorbent, the kinetics of reduction of $\mathrm{Pu}(\mathrm{V})$ was estimated. The results of this experiment are represented in Table 4.

As can be seen, after an hour contact with the sorbent up to $90 \%$ of $\mathrm{Pu}(\mathrm{V})$ is reduced to $\mathrm{Pu}(\mathrm{IV})$. Experiments with

${ }^{238} \mathrm{Pu}$ allowed one to deal with the trace concentrations of plutonium were in a rather good agreement with the experiment under dynamic conditions, where a plutonium concentration of $7.93 \times 10^{-6} \mathrm{M}$ was used: the Pu sorption up to $85 \%$ was demonstrated. After desorption by $5.0 \mathrm{~mL}$ of $0.1 \mathrm{M} \mathrm{HNO}_{3}$ solution, $60.7 \%$ of plutonium was found in the eluate. Further assessment of the speciation of $\mathrm{Pu}$ in the eluate showed that it contains $88 \%$ of $\mathrm{Pu}(\mathrm{V})$ and $10 \%$ of $\mathrm{Pu}(\mathrm{IV})$. The following elution with a $5-\mathrm{mL}$ portion of $0.35 \mathrm{M} \mathrm{HNO}_{3}+0.01 \mathrm{M}$ solution recovered the residual plutonium completely. This second portion of the eluate contained $25.7 \%$ of the total amount of the sorbed plutonium in which $2 \%$ of $\mathrm{Pu}(\mathrm{V})$ and $97 \%$ of $\mathrm{Pu}(\mathrm{IV})$ were determined.

\section{Conclusions}

The experiments showed the feasibility of using DIAPAK C16 cartridges modified by BPHA to extract plutonium in various oxidation states from simulated groundwater solutions within a $\mathrm{pH}$ range of 7-9. The sorption degree depends on the plutonium oxidation state. $\mathrm{Pu}(\mathrm{IV})$ is extracted by $98-99 \%$ regardless of the volume and the flow-rate of passing the solutions under study. $\mathrm{Pu}(\mathrm{V})$ is extracted by $90-95 \%$ from $10 \mathrm{~mL}$ of $\mathrm{SGW}$ (the contact time is $10 \mathrm{~min}$ ) and by $75-80 \%$ from $100 \mathrm{~mL}$ of SGW (the contact time is $100 \mathrm{~min})$. Up to $50 \%$ of $\mathrm{Pu}(\mathrm{VI})$ retains on the SPE cartridge from $100 \mathrm{~mL}$ of SGW. About $74 \%$ of plutonium can be extracted from $100 \mathrm{~mL}$ of SGW solution containing the equal concentrations of $\mathrm{Pu}(\mathrm{IV}), \mathrm{Pu}(\mathrm{V})$, and $\mathrm{Pu}(\mathrm{VI})$.

Kinetic exchange capacities of plutonium in all the oxidation states do not change considerably during the sorption process. On the other hand, the distribution coefficient varies depending on the plutonium speciation.

During an hour sorption, $80-90 \%$ of $\mathrm{Pu}(\mathrm{V})$ is reduced to $\mathrm{Pu}(\mathrm{IV}) . \mathrm{Pu}(\mathrm{VI})$ is reduced to $\mathrm{Pu}(\mathrm{V})$ and $\mathrm{Pu}(\mathrm{IV})$ by 34 and $55 \%$, respectively. The sorption of mixed-valent plutonium resulted in the formation of $\mathrm{Pu}(\mathrm{V})$ and $\mathrm{Pu}(\mathrm{IV})$ under the equilibrium conditions.

Acknowledgments This study was supported by the Federal Special Program "Scientific and science-educational personnel of innovation Russia" for 2009-2013s (state contract No. P-493 from 13.05.2010). The authors would like to thanks prof. A.Timerbaev for meticulous and detailed suggestions that substantially improved this article.

Open Access This article is distributed under the terms of the Creative Commons Attribution Noncommercial License which permits any noncommercial use, distribution, and reproduction in any medium, provided the original author(s) and source are credited.

\section{References}

1. Katz JJ, Seaborg GT, Morss LR (2006) The chemistry of the actinide elements, 3rd edn. Chapman and Hall, New York, pp 1125-1132

2. Novikov AP, Myasoedov BF (2003) Radiochemical procedures for speciation of actinides in the environment. In: Environment Protection against Radioactive pollution, pp 147-154

3. Qiao J, You X, Miro M, Roos P (2009) Determination of plutonium isotopes in water and environmental solids. Anal Chim Acta 652:66-84

4. Spivakov BYa, Malofeeva GI, Petrukhin OM (2006) Solid-phase extration on alkil-bonded silica gels in inorganic analysis. Anal. Sci 22:503

5. Kholin YuV (2000) Quantitative physical-chemical analysis complexing in solutions and on a surface chemically modified silica. Folio, Kharkov, pp 244-250

6. Pilipenko AT, Zulfigarov OS (1980) Hydroxamic acids. Nauka, Moscow

7. Stary J (1966) The solvent extraction of metal chelates. Mir, Moscow, p 179

8. Chmutova MK, Petrukhin OM, Zolotov YuA (1963) Extraction of chelating compounds of plutonium and other elements with $N$ benzoylphenylhydroxylamine. J Anal Chem 18:588-594

9. Kuzovkina EV, Malofeeva GI, Petrukhin OM et al (2009) Recovery of $\mathrm{Np}(\mathrm{V})$. Pu(IV). and Am(III) by solid-phase extractions with supported $\mathrm{N}$-benzoylphenylhydroxylamine. Radiochemistry 51(1):26-29

10. Choppin GR, Bond AH, Hromadka PM (1997) Redox speciation of plutonium. J Radioanal Nucl Chem 219(2):203-210

11. Perevalov SA, Molochnikova NP (2009) Sorption of Pu in various oxidation states onto multiwalled carbon nanotubes. J Radioanal Nucl Chem 281:603-608

12. Kulyako YuM, Perevalov SA, Malikov DA et al (2010) Sorption of plutonium in various oxidation states on multiwalled carbon 
nanotubes "taunit" from aqueous solutions. Radiochemistry 52(3):234-237

13. Perevalov SA, Kulyako YuM, Vinokurov SE et al (2009) Sorption of $\mathrm{Pu}(\mathrm{IV})$ in the polymeric colloidal form on rock typical of "mayak" production association area. Radiochemistry 51(4): 327-331
14. Kulyako YuM, Perevalov SA, Trofimov TI et al (2009) Disproportionation of polymeric $\mathrm{Pu}(\mathrm{IV})$ in weakly acidic solutions. Radiochemistry 51(4):323-326 